\title{
JUDEOFOBIA EN CHILE DURANTE LA DÉCADA DEL OCHENTA: LA OBRA DE MIGUEL SERRANO
}

\author{
Gustavo Guzmán Castro \\ Licenciado en Historia, Universidad de Chile \\ gu.guzman@gmail.com
}

\begin{abstract}
RESUMEN
Desde la llegada de los primeros sefardies durante la Colonia, la comunidad judia ha debido enfrentar variados desafios, siendo la judeofobia el más persistente y peligroso. La judeofobia ha provenido de distintos frentes, pero con especial intensidad desde la extrema derecha, específicamente de su ala nazi. A lo largo del siglo XX, los protagonistas de la judeofobia chilena de extrema derecha fueron variando: es asi como desde la década del ochenta, y coincidiendo con la decadencia de la línea WUNS de Franz Pfeiffer, la figura de Miguel Serrano se erige sin contrapeso al interior del nazismo chileno, a la vez que se instala como el principal ideólogo judeófobo de habla hispana. En este artículo analizaremos las obras de este período, destacando los principales aportes de Serrano al discurso judeófobo de extrema derecha en español, y concluiremos con una reflexión sobre el funcionamiento de su judeofobia desde un punto de vista semiótico. Creemos que al hacerlo contribuimos a la labor de estudio y posterior "desbaratamiento discursivo" de los grupos de extrema derecha actuales.
\end{abstract}

Palabras Clave: judeofobia, antisemitismo, nazismo, Chile.

\begin{abstract}
Since the arrival of the early Sephardim during the Colony, the Jewish community has faced many challenges, being the judeophobia the most persistent and dangerous. This judeophobia has come from many fronts, especially from the far right and its Nazi wing. During the eighties of the last century the major figures of the Chilean judeophobia of far right changed: coinciding with the fall of Franz Pfeiffer's WUNS brand, the figure of Miguel Serrano raised as the most important Chilean Nazi and judeophobic thinker in Spanish language. In this paper we will analyze the judeophobic books of this period, with emphasize in his main contributions to the judeophobic discourse of far right in Spanish language, and we will finish with a reflection about the operation of his judeophobia from a semiotic point of view. We think that when we do it, we are contributing to the study and to break down the discourses of the present far right groups.
\end{abstract}

KEY Words: Judeophobia, anti-Semitism, Nazism, Chile. 


\section{INTRODUCCIÓN}

Desde la llegada de los primeros sefardies a Chile en tiempos de la Colonia, la comunidad judía ha debido enfrentar una serie de desafios, siendo la judeofobia el más persistente y peligroso. Este desafio ha provenido - como en muchas otras partes, no solo en Chile- de distintos frentes': de la Iglesia católica - o cuando menos de católicos provistos de una odiosidad antijudía muchas veces cercana a la superstición-; de miembros radicalizados de la comunidad árabe, próximos a un discurso de extremismo musulmán; de la extrema izquierda y, sobre todo, de la extrema derecha. Creemos que, pese a la importancia de todos estos actores en la historia de la judeofobia moderna, el actor principal ha sido la extrema derecha, especialmente el ala nazi.

A continuación, una breve cronología del desarrollo de esta corriente en Chile desde comienzos del siglo XX hasta nuestros días, destacando sus principales etapas.

- Primer cuarto de siglo: paralelamente a la larga tradición judeófoba católica, enraizada en la cultura hispánica (tradición que, creemos, ni siquiera hoy ha desaparecido del todo, no obstante su debilitamiento), se desarrolla una corriente de judeofobia secular, caracterizada por cierto "entusiasmo científico", darwinismo social, y que frecuentemente concibe a los judíos como raza. En el caso de Chile, esta ideologia fue, por cierto, una importación europea. El principal hito de este periodo es la publicación de Raza Chilena (1904) de Nicolás Palacios, que tuvo una influencia poco despreciable entre cierta intelectualidad nacional. "Al escribir antes de que Chile tuviera una comunidad judía digna de atención, Palacios criticó a judios imaginarios, que representaban las fuerzas modernas que despreciaba"2.

- Décadas del treinta y cuarenta: movimientos y partidos de derecha que emulan a - o cuando menos se inspiran muy fuertemente en- sus pares europeos, se instalan como principales protagonistas de los discursos judeófobos. El más importante de ellos, no tanto por la profundidad ideológica de su judeofobia sino por su peso y por la utilización política que hacian de los sentimientos antijudios para la movilización de masas, es el Movimiento Nacional Socialista chileno, de Jorge González Von Marées. Para Sandra McGee Deutsch, el MNS chileno entra en la categoria de fascista, $y$ "al identificar el capitalismo con la codicia, la usura (...) más que con la propiedad privada, pudieron presentarse a sí mismo como opuestos a él. Como a menudo asociaron esos rasgos nocivos con los judíos sustituyeron la lucha de clases por el antisemitismo". De ahí su importancia en la historia de la judeofobia en Chile.

The Project for the Study of the Antisemitism, Anti-jewish Propaganda 1991. Tel Aviv University, 1992, p. 8.

2 Deutsch, S. M. Las derechas. La extrema derecha en la Argentina, el Brasil y Chile. 1890-1939, Bs. As., Universidad Nacional de Quilmes Editorial, 2005, p. 39. 
Sin embargo, la judeofobia de este movimiento no era comparable, en la práctica, al del NSDAP (el partido nazi alemán) $)^{3}$.

Y a diferencia de lo que ocurría con Palacios, el discurso de este movimiento es contemporáneo a un flujo inmigratorio significativo de judios, muchos de los cuales huían, precisamente, de los nacionalsocialistas alemanes ${ }^{4}$. Hacia 1941 había alrededor de veinte mil judios en Chile, de los cuales unos dieciocho mil vivían en Santiagos.

- Décadas del cuarenta y cincuenta: tras el fin de la Segunda Guerra mundial y la difusión planetaria del horror de la Shoah los discursos judeófobos occidentales tienden a replegarse, al menos por unos años. En este período, los principales portavoces de la extrema derecha y la judeofobia en Chile serán el Partido Nacional Fascista y la Vanguardia Popular Socialista (lo que quedó del MNS) ${ }^{6}$.

- Décadas del sesenta y setenta: en el mismo año en que se jugaba el mundial de fútbol de Chile, se formó en Santiago el Partido Nacional Socialista Obrero Chileno (PNSO$\mathrm{CH}$ ), dirigido por Franz Pfeiffer, como agrupación afiliada a la "Internacional Racista", la W.U.N.S. (World Union of National Socialist), con centro en EE.UU. El partido de Pfeiffer sería ilegalizado a fines de 1964 y Pfeiffer encarcelado por ataques contra judios? El PNSOCH fue "el caso más apropiado de un origen orgánico, militante y organizado, de explícito y directo neonazismo es este Partido Nacional Socialista Obrero"8. Esta línea WUNS perderia fuerza en los ochenta, y en la misma medida que lo hacía, Serrano se levantaba como la principal figura del nazismo chileno.

- Década del ochenta hasta la masificación de Internet (fines de los noventa): es el período de la hegemonía sin contrapeso de Miguel Serrano al interior de la escena neonazi chilena $y$ de la judeofobia en lengua española.

- Fines de los noventa hasta hoy: es la época del "nazismo virtual" en la que vivimos, fenómeno estudiado por el profesor Isaac Caro'.

"Aunque el MNS chileno no puede ser considerado una copia fiel del nacionalsocialismo alemán, igualmente éste intentaba "seproducir" el movimiento alemán. Sin embargo, tanto Carlos Keller como Jorge González Von Marées (...) se distanciaron del antisemitismo biológico y racial puro". Wojak, I. "Chile y la inmigración judeoalemana", en Milgram, A. (ed.), Entre la aceptación y el odio. América Latina y los refugiados judios del nazismo, Jerusalén, Yad Vashem, 2003, pp. 151-152.

Avni, H. Judios en América, Madrid, Mapfre, 1992, p. 273.

Deutsch, S. M. Op. cit., p. 217.

Saavedra, M. "El neonazismo en Chile", articulo inédito, p. 3.

Casals, X. Ultrapatriotas. Extrema derecha y nacionalismo de la guena fria a la era de la globalización. Barcelona, Crítica, 2003, pp. 176-177.

Saavedra, M. Op. cit, pp. 3-5.

Caro, 1. Extremismos de derecha y movimientos neonazis. Berlin, Madrid, Santiago. Santiago de Chile, LOM, 2007. 
El objeto de nuestro estudio es la obra de Miguel Serrano durante la década de 1980, en cuanto la mayor contribución hecha desde Chile a la tradición antijudía en lengua española y a la judeofobia contemporánea de extrema derecha. El período escogido es precisamente aquel en el cual se forja su sitial de privilegio al interior del nazismo chileno y, sobre todo, de la escena neonazi mundial. Un silial que, sin duda, es central ${ }^{10}$. Es más, creemos que no nos equivocamos al afirmar que se trata del más importante ideólogo de la judeofobia en habla hispana de la segunda mitad del siglo XX, importancia que se ha acrecentado durante la última década gracias a Internet ${ }^{\mathrm{H}}$.

De ahi entonces el interés por estudiar la obra de este autor: por medio de sus innumerables libros, articulos y entrevistas, además de su labor editorial, no solo ha difundido viejas ficciones antijudías (en especial en el mundo hispanoparlante) sino que ha hecho aportes significativos a la tradición judeófoba con peculiares interpretaciones de la historia contemporánea. Estos relatos son altamente apetecidos por neonazis de todo el mundo, incluidos grupos europeos y norteamericanos $^{12}$, y Serrano sabe proveerlos con copioso material: entre 1978 y 2003 escribió 19 obras explícitamente judeófobas, además de prologar y editar (incluso traducir) cinco "clásicos" antijudíos. A nivel nacional e internacional sus obras más importantes son, indudablemente, aquellas que forman la llamada "Trilogía del Hitlerismo Esotérico", a saber: El cordón dorado. Hitlerismo Esotérico (1978), Adolf Hitler, el último Avatara (1982) y Manu. Por el hombre que vendrá (1991). Son éstas las que más prestigio le han granjeado al interior de la escena neonazi mundial, siendo traducidas al inglés y al alemán. Y si bien Adolf Hitler, el último Avatara, la obra más importante de la trilogía, fue publicada en 1982, creemos que debido a su extensión e importancia merece un estudio aparte. Por ende no la hemos considerado aqui.

En suma, las obras de las que nos ocuparemos son las siguientes:

Los Protocolos de los Sabios de Sión y su aplicación en Chile (1981)

El ciclo racial chileno (1985)

La resurrección del Héroe (1986)

Nacionalsocialismo, única solución para los pueblos de América del Sur (1986)

Contra la usura (1987)

El Plan Andinia. Estrategia sionista para apoderarse de la Patagonia chilena y argentina (1987).

El Informe Leuchter: Fin de una mentira (1989)

10 Casals, X. Op. cit., p. 189.

1 libid, p. 199.

12 Goodrick-Clarke, N. Hitler's Priestess. Savitri Devi, the Hindu-Aryan Myth and Neonazism. New York, New York University Press, 1998, pp. 221-222. 
En primer lugar revisaremos los textos escritos de su puño y letra, para luego pasar a los "clásicos" antijudios editados, prologados y difundidos por él en Chile y Latinoamérica. Luego analizaremos cuáles son los principales aportes de su obra de los ochenta a la judeofobia contemporánea de extrema derecha, para concluir con una reflexión semiótica sobre el funcionamiento de su judeofobia.

Creemos que al hacerlo contribuimos al conocimiento no solo del nazi chileno más importante de las últimas décadas, sino del principal ideólogo judeófobo en lengua hispana. Y, considerando la importancia de los movimientos neonazis latinoamericanos al interior de la escena mundial ${ }^{13}$ en general, y de Miguel Serrano en particular, creemos que esto constituye un aporte a la labor de estudio y de posterior "desbaratamiento discursivo" de los grupos de extrema derecha actuales.

\section{EL REGRESO A CHILE Y LAS OBRAS DE LOS OCHENTA}

En 1952, a poco de ser electo Presidente de la República, Carlos Ibáñez del Campo designa a Miguel Serrano, escritor de 35 años de edad, como encargado de negocios de Chile en India, donde luego sería ascendido a embajador. Así comenzaba una carrera diplomática de dos décadas que vería su fin con la llegada de Salvador Allende a La Moneda. Su salida del servicio diplomático se produjo mientras se desempeñaba en Europa central, tras lo cual Serrano optó por permanecer viviendo en Europa y aprovechar la red de contactos con connotados nazis europeos que tendió mientras se desempeñaba representando al Estado chileno.

\section{Recién a comienzos de la década del ochenta decide regresar a Chile.}

Una de las primeras apariciones públicas de importancia de Miguel Serrano tras su retorno se produjo con motivo de la muerte del SS Walther Rauff en 1984. Rauff era un criminal de guerra nazi, directamente implicado en la ejecución de judios durante la Shoah, que huyó a Chile, donde prosperó gracias a sus empresas pesqueras del extremo sur. Si bien Rauff fue requerido en más de una ocasión por crímenes de lesa humanidad, el Estado chileno, a través de su poder judicial, como del ejecutivo, se negó a extraditarlo, argumentando prescripción de aquello de lo que se le acusaba. Su solitario funeral, seguido por periodistas chilenos y extranjeros, quedó en la memoria de la opinión pública por el "homenaje" que Serrano rindiera al difunto: brazo en alto

13 "El panorama neonazi latinoamericano, conformado a partir de movimientos y medios, que reivindican en forma explicita la ideologia del nacionalsocialismo y el liderazgo representado por Hitler, no constituye un hecho netamente marginal del neonazismo mundial. No se puede hablar, en estos casos, de la existencia de un centro -con sede en Europa y Norteamérica- y una periferia -conformada por América Latina. Por el contrario, el neonazismo latinoamericano forma parte integral del escenario neonazi mundial, lo que queda ejemplificado con la importancia mundial que tienen los servidores de Internet como "Libre Opinión" y el reconocimiento de ideólogos como Miguel Serrano”. Caro, 1. Op. cit. . pp. 190-191. 
y gritando “ ¡Heil Hitler!”, Serrano despedía al criminal de guerra. Las fotos dieron la vuelta al mundo, las entrevistas llegaron solas, y el objetivo se consiguió: figurar.

A continuación revisaremos las obras escritas de su puño y letra durante la década del ochenta, para luego abordar su trabajo como difusor de "clásicos" textos judeófobos durante la misma década.

\section{EL CICLO RACIAL CHILENO (1985)}

En junio 1982 la Academia Nacional de Seguridad invitó a Miguel Serrano a dar una charla sobre Nicolás Palacios ${ }^{14}$. El texto con el que nos enfrentamos -que el autor dedica al ejército de Chile- sería la versión escrita, aunque retocada, de dicha charla. Ésta comienza con una exposición de las ideas de Palacios sobre la composición étnica de Chile (creencia en el "mestizaje parejo" entre araucanos y visigodos), tras lo cual Serrano declara -pese a su obvia admiración por Palacios- su disenso con éstas. Está convencido de que "el mestizaje chileno, como todo mestizaje, es malo y se encuentra ya en plena descomposición"15. Luego expone las ideas racistas de Gobineau y reconoce que su propia "visión, como la de Gobineau, es apocalíptica y sin esperanzas"16.

Este "ciclo racial chileno" habría seguido, según Serrano, las siguientes etapas:

1. Conquista y Colonia caracterizadas por "la vida heroica del campamento guerrero, con su espíritu gótico y germánico".

2. En la Colonia "predominan aún los nobles sin pergaminos, los hidalgos, separados casi en castas de los comerciantes, de los escribientes, etc. Ya han traído sus mujeres de Europa, pero el nuevo mestizaje está en marcha".

3. "Con la Independencia y la aparición de Portales (...) vienen los decenios de gobierno impersonal, sobrio, honesto, de los hombres probos y pobres (...) Gobierna la casta en que todavía predomina el espíritu gótico".

4. "La Revolución del 91 (...) señala el ascenso del mestizaje de un color más subido".

5. "Con la aparición del político Arturo Alessandri Palma, la descomposición aumenta de modo que se hará necesaria la intervención del coronel Carlos Ibáñez del Campo. Desgraciadamente, no puede restaurar ya el estilo portaliano-gótico".

6. "Las décadas del Frente Popular y de los gobiernos radicales significan la llegada a las alturas del elemento andaluz -picunche-semita. Lo que sigue, con algunos interregnos, no es más que la fatal pendiente de la descomposición del mestizaje en Chile".

Serrano, M. El ciclo racial chileno, Santiago, 1985, p. 3.

Ibid, p. 9.

Ibid. 
7. "Con la llamada Unidad Popular, de Salvador Allende Gossens, es el indio mongólico y el negro cubano, más el judío, los que se establecen en el poder"'?

La presencia judía en Chile sería dañina, según el autor, por cuanto "el objetivo principal del judio es la liquidación del campo, de la tierra, por representar la sangre y la tradición, esencia de toda nacionalidad, sea en forma directa con el marxismo, con la reforma agraria y la colectivización, con el minifundio, como lo intentaran en Chile el judío democratacristiano Chonchol y el socialista, también judio, Allende Gossens; o bien, de un modo indirecto, en forma más sutil y artera, con el librecambio, el monetarismo y el consumismo capitalistas de un Friedman o de los economistas de su "Escuela de Chicago" "18.

Luego refuerza esta representación antijudia echando mano de una sus clásicas fórmulas: el comunismo y el capitalismo "son igualmente destructores de la nacionalidad. En aparente contradicción, se apuntalan mutuamente, ya que no pueden existir el uno sin el otro. Y arriba, en la cúspide de la trilogia sin nombre, el tercero que nadie se atreve a mencionar, porque se tiembla ante la sola presencia de su sombra: el dueño de los rayos y del trueno, que se reverencia hasta la genuflexión, por terror a que nos destruya junto con el universo: el judio internacional" ${ }^{n 19}$.

Tras estas afirmaciones inauditas, expresadas ante generales, almirantes y otros funcionarios públicos, Miguel Serrano concluye con la siguiente recomendación: "Chile debe cerrar definitivamente las puertas al asiático, al chino, al japonés, al vietnamita, al coreano, al negro, al judio, y abrirlas al alemán, al nórdico europeo, entregándoles el lejano sur para colonizarlo"200.

\section{LA RESURRECCIÓN DEL HÉROE (1986)}

Reunido con otros nazis chilenos con motivo del aniversario 97 del nacimiento de Hitler, "en el año 97 de la Nueva Era Hitleriana", o sea el 20 de abril de 1986, Serrano leyó el documento que constituye la base de este libro. La justificación del autor para su lanzamiento es la pronta "visita que a este pais hará ese funesto personaje que es el Papa de la iglesia judia de Roma, quien, conjuntamente con la Gran Sinagoga y las Logias Masónicas, prepara ya el advenimiento del Mesías Judío"'21.

El texto comienza diferenciando "kristianismo" ("verdadero") de "cristianismo" ("invención judaica"): "las siguientes páginas no son anti-kristianas, del verdadero Kristianismo (con $K$ ), el de los arios, que ha preservado su tesoro esotérico y mágico y que es el Kristianismo de Wotan y los griegos. Estas páginas son profundamente anticristianas, del cristianismo judío de Saulo, de Pablo de Tarso, que fuera inventado por un judío, como el marxismo, y controlado por judios,

lbíd.

Ibid., p. 36.

lbid., p. 53.

Serrano, M. La resurrección del héroe, Santiago, 1986, pp. 11-12. 
hasta el presente"22. El cristianismo sería un invento judio, un arma para dominar a los gentiles: "Se ha pretendido hacer aparecer al cristianismo en aparente oposición con la historia nacional de los judios; los Evangelios con el Antiguo Testamento, ambos inventados y falsificados del comienzo al fin. Que esta oposición no es tal, ha venido a manifestarse (...) cuando el Papa ha visitado la Sinagoga de Roma para rendir pleitesía a sus "hermanos mayores", los Rabinos judios. (...) nunca, en casi dos mil años, existió esa pretendida oposición entre cristianos y judíos. Ambos trabajaban por idéntica causa y para el mismo Amo absoluto, para el Uno. Ambos siempre fueron monoteístas, servidores del Uno, del Demiurgo, Jahvé, y enemigos de los godos, de los arios, de la Raza Pura de los Arios. (...) El cristianismo no fue más que el anzuelo con que el judaísmo cazó incautos arios, neutralizándolos, castrándolos (...) La aparente oposición entre cristianismo y judaísmo ha sido una hábil trampa demiúrgica, semejante a la que hoy se tiende con la simulada oposición entre marxismo y capitalismo. Solo que la trampa cristiana ha estado activa por casi dos mil años"23.

Y, según Serrano, "dos fueron los conceptos fundamentales que Pablo, inspirado por el Demiurgo, introdujera en la nueva religión (...) la idea del Pecado Original de todos los hombres (...) El segundo postulado consistió en la igualdad de todos los hombres y de todas las razas. (...) Estas dos premisas eran absolutamente falsas e inventadas por el judaísmo, que nunca ha creido en ellas, para envenenar y destruir a los goym"24.

Por último, Serrano relaciona todo lo dicho hasta allí con los Protocolos de los Sabios de Sión y su creencia en la conspiración judía mundial, e identifica a Jahvé -como Dios de los judíoscon el Demiurgo y el Demonio: "Es imposible que un solo hombre haya podido conseguir tanto como ese Pablo de Tarso. El plan secreto tiene que haber sido elaborado por una sinarquia selecta de rabinos iniciados en una religión de sangre (de anti-sangre) racista (de anti-raza), de cabalistas sabios, una elite de magos negros, la que vendría a ser conocida por el resto del mundo como los Sabios de Sión. Dictarian su apoyo a Saulo (...) brindándole su apoyo secreto, asi como lo hacen hoy los servicios de inteligencia con sus agentes más hábiles, y como lo harian siglos después con Marx, con Freud y con Einstein. La masa judia también deberá ignorar el fondo del asunto. Sin embargo, aun esto no es suficiente para una conspiración de tales dimensiones, tan tremendamente diabólica. De allí trasciende un elemento sobrehumano, la presencia de una Fuerza desconocida y terrible. Eso que se ha llamado el Demonio y que es el Demiurgo, el Dios de los judios, Jahvé (...) Íbamos derecho al abismo, sin esperanza, sin salida. Hasta que los Dioses mismos del Walhalla, al finalizar la Era de Piscis, en el nadir del Kaliyuga, decidieron venir en ayuda del prisionero encadenado, de los guerreros (...) Enviaron a Adolf Hitler, el Último Avatara, para que despertara a los héroes dormidos, cortara sus cadenas y deshiciera el embrujo del Demiurgo, pudiendo enfrentarlo en el combate decisivo, antes de la entrada en la Edad de Acuario. (...) Al comenzar la Era de Acuario, Hitler ha hecho posible la Resurrección del Héroe"2s. 
Para Serrano, el nacionalsocialismo se basa en dos pilares: "la concepción racista de la Historia", abordada en la primera parte del libro, "y una especial ideología económica", revisada en la segunda. Desde ambos puntos de vista, él cree que el nacionalsocialismo está vigente en América del Sur.

En primer lugar, intenta explicar qué es el racismo nazi: "El racismo de los hitleristas consistía en un intento de retomar al origen puro (...) limpiando la raza y la sangre (...) Una cria preparada de la especie humana, una regeneración de la sangre, de la biología y del espíritu. (...) Así entendido, el racismo, en su exacta perspectiva, nos permite comprender que el Nacionalsocialismo no tiene por qué excluirse de los países mestizos de la mal llamada América Latina, teniendo que depender su aplicación del mayor o menor grado de bastardismo, o mestizaje alcanzado" ${ }^{26}$. Con argumentaciones de este tipo, Serrano intenta soslayar la lógica objeción a adscribir al nazismo-doctrina esencialmente racista, además de judeófoba-en un continente y en un país mestizo. Para ello recurre también a argumentaciones propias de Nicolás Palacios: "Chile no fue nunca, ni lo es todavía, un país "latino", o "latinoamericano". Fue un país indo-germánico, germano-americano"27.

Luego pasa revista a la "especial ideología económica" nacionalsocialista. A modo de introducción se refiere al origen de los judios: "¿Qué es el judío? No creo que algún ario se encuentre hoy en condición de poder descifrar totalmente este misterio oscuro. Hábilmente y con maña han sido borradas las huellas del origen. (...) Hitler define al judio de la siguiente manera: "No es un nómade, es un parásito", que se enquista en la vida y cuerpo de otros pueblos y les succiona su energía vital creadora. Como un drácula, bebe su sangre. $Y$ así le es dado perdurar casi eternamente. El judio no crea nada propio, únicamente plagia la creación de los otros, de los arios, y la corrompe. La misma Biblia no le pertenece, un documento trunco, adulterado, expoliado. (...) Por esto, en la Biblia no es posible descubrir nada auténtico sobre el origen verdadero del judío. Porque el judío no es el hebreo, ni es el israelita, términos ambos que se referían a otros seres"28.

Pues cree que "para poder penetrar en profundidad el sistema económico y social del hitlerismo, se hace necesario descubrir la hábil y siniestra trampa con que el judío ha aprisionado al mundo no judío: el interés del capital. La Usura"29.

El mérito de Hitler consistiria, entonces, en combatir la usura: "Una vez en el poder, Hitler se niega a aceptar el interés usurero. (...) Además, y esto es lo más importante, se acaba la Usura. Santiago, 1997], p. 15.

27 [bid., p. 16.

28 Ibíd., p. 25 .

$29 \quad$ Ibid., p. 35. 
Al mismo tiempo se comienza a limpiar la raza (...) El golpe iba dirigido al corazón de la Gran Conspiración universal contra la raza blanca, contra el hombre ario, contra el no-judio. De lograr imponerse totalmente el sistema Nacionalsocialista, por convicción y por ejemplo, no por la imposición de la fuerza o la violencia, el caldo de cultivo del virus judio, ese cáncer para los no judios quedaría totalmente destruido. Y el judío desaparecería, devorándose a sí mismo, en el furor impotente de su desesperación. Volveria el aguijón en contra suya" ${ }^{\text {"30. }}$.

Por último, Serrano intenta explicar la historia económica reciente de Chile a través de los Protocolos de los Sabios de Sión: "La Escuela Monetarista de Chicago no es más que la realización de unos pocos Protocolos de los Sabios de Sión. Milton Friedman, o como sea su verdadero nombre judio (...) no ha hecho más que ponerlos en práctica en Chile"31. Y ante el panorama apocalíptico de esta representación, propone que "mientras seamos capaces de continuar en la gloriosa misión de revelar la verdadera Historia de nuestro mundo, dando a conocer la trama de la Gran Conspiración y la Epopeya Granđiosa del Hitlerismo, también debemos declarar, con irreductible fe, que la única solución aún posible para los pueblos de la América del Sur y del mundo es el Nacionalsocialismo, tal como aquí lo hemos explicado." 32

\section{LABOR EDITORIAL Y PROPAGANDISTICA}

\section{Los PRotocolos de LOS SABIOS DE SHÓN Y SU APLLACAÓN EN CHILE (1981)}

Lo primero que Serrano publica a su llegada de Europa es el más clásico texto antijudio: los Protocolos de los Sabios de Sión. Para darle un perfil más local y hacer más fácil su difusión escribe un prólogo que le dará su nombre definitivo al texto: Los Protocolos de los Sabios de Sión y su aplicación en Chile.

Este "clásico" de la judeofobia -que no es sino una falsificación llevada a cabo por la policía secreta zarista a comienzos del siglo XX-constituye la perfecta versión escrita del mito de la conspiración judía mundial, según la cual "existe un gobiemo secreto judío que, mediante una red mundial de organismos y organizaciones camuflados, controla partidos políticos y gobiernos, la prensa y la opinión pública, los bancos y la marcha de la economía. Se dice que el gobierno secreto hace todo eso conforme a un plan secular y con el único objetivo de lograr que los judíos dominen el mundo entero, y también se dice que se está acercando peligrosamente al logro de ese objetivo"33. Los Protocolos se basan en la creencia en esta "superstición politica" ${ }^{\text {"34 }}$ según la cual

30 Ibid., pp. $39-40$.

3 Ibid., p. 46.

32 lbíd., pp. 63-64.

33 Cohn, N. El mito de la conspiración judia mundial: los Protocolos de los Sabios de Sión, Madrid, Alianza, 1983, p. 19.

34 Ibíd., p. 21. 
existiría un gobiemo secreto mundial en manos judias que controla y dirige la Historia desde las sombras para beneficio propio.

Podemos resumir dicho prólogo de la siguiente manera: desde hace miles de años existe una conspiración secreta judía (ignorada por muchos judios, que también son sus víctimas ${ }^{35}$ ), que se propone dominar y destruir a los no judíos. Para lograr dicha meta, se han servido de su más despiadado invento: la usura, que les permite vivir sin trabajar, enriqueciéndose a costa de los gentiles $^{36}$. El espíritu de esta conspiración es reconocible ya en la Torah y el Talmud ${ }^{37}$. Sin embargo, al entrar en los tiempos modernos, los Sabios de Sión -cerebros de la conspiración- deciden reunirse con el fin de fijar nuevas estrategias, acordes a la época, que les permitan hacerse del poder total del mundo. Deciden convocar a un cónclave en Basilea el año 1897. Es el primer congreso sionista mundial. Y el texto que conocemos como los Protocolos de los Sabios de Sión son las conclusiones de dicho congreso ${ }^{38}$, las cuales se habrian filtrado de una manera poco clara. Una vez producida la "revelación" de los Protocolos al mundo no judío, la conspiración mundial, el gobiemo secreto mueve todos sus hilos para desprestigiarlos ${ }^{39}$, condenándolos a ser ignorados por la masa (lo mismo ha hecho con Nicolás Palacios, "el más grande pensador y escritor de las Américas y de las Españas, el único que valga la pena de mencionar y leer"40). Para Serrano, los Protocolos son un documento revelatorio: los judios dominan el capitalismo y el comunismo; la masonería y el Vaticano, a todas las sectas religiosas menores, al terrorismo, etc. Así por ejemplo, manipulan el capitalismo y el comunismo para que parezcan contrarios entre sí, y de este modo despisten a los gentiles, haciéndolos presas más fáciles de sus planes de dominación ${ }^{41}$. Dicho de otro modo, el capitalismo y el comunismo, solo aparentemente opuestos, son una misma cosa: instrumentos judios de dominación mundial. Lo mismo ocurre con la Iglesia católica y la masonería.

En suma, la historia contemporánea toda, pero en particular la historia reciente de América del Sur y de Chile, se reducen a la mera aplicación de los Protocolos ${ }^{42}$.

Concluye exhortando a los "jóvenes camaradas" a dar a conocer este "libro revelador"43.

Los Protocolos de los Sabios de Sión y su aplicación en Chile. Santiago, 1981 [2ªd., León, Wotan, 1988 , p. 32].

Ibid., p. 33.

Ibid, p. 32.

[bid., pp. 32-33.

Ibid, p. 30.

Ibid., p. 30 .

lbid., p. 34.

Ibid, p. 35 .

ibid., p. 38 . 

(1987)

El origen de esta verdadera actualización sudamericana de los Protocolos de los Sabios de Sión es argentino. Según Leonardo Senkman, durante los últimos años del justicialismo en el poder, "en la doctrina peronista se cristalizaron ciertos elementos ideológicos (...) para promover un clima de perturbación antisemita. El más importante de estos elementos fue el de la teoría conspirativa de la Sinarquia Internacional ${ }^{344}$. Este escenario, propicio para interpretaciones conspirativas, alcanzó su clímax con la aparición de El Plan Andinia, texto judeófobo según el cual "el sionismo se propondría segregar parte del territorio de la Patagonia y fundar un Estado judío". El Plan fue denunciado en 1971 por el nacionalista Walter Beveraggi Allende ${ }^{45}$. El parentesco de este texto con los Protocolos de los Sabios de Sión es evidente.

En cuanto a la edición chilena, ésta es presentada como fruto de la colaboración de "nacionalistas chilenos y argentinos" conscientes de que el Plan Andinia afecta a ambos países ${ }^{46}$, y está dedicada a "las juventudes nacionalistas de América del Sur, a los hombres libres, a los civiles y militares patriotas, aún no instrumentalizados por la masonería y las iglesias al servicio del Imperialismo de Sión"47.

Además de editarlo, Serrano prologa y comenta el libro. El prólogo se resume así: existe un gobierno mundial secreto en manos judias, que dirige el capitalismo, el comunismo, la masonería, la lglesia, sectas menores, terrorismo, etc. Este gobiemo secreto judio se ha propuesto arrebatar la Patagonia a Chile y a Argentina para construir alli un segundo estado judio ${ }^{48}$. La historia contemporánea de Latinoamérica se hace más clara a la luz de las revelaciones del Plan Andinia $^{49}$, el cual provee una suerte de clave para la comprensión de dicha historia. Toda la historia reciente del continente está dirigida al cumplimiento del Plan. Asi, por ejemplo, Serrano afirma que el conflicto chileno-argentino de fines de la década de 1970 que casi desemboca en guerra solo es comprensible a la luz de las revelaciones del Plan: la existencia de regímenes militares en ambos paises ponía en jaque el cumplimiento del Plan, por lo que los conspiradores llevaron a estos países hermanos al borde de la guerra. También "detrás del atentado de muerte contra Pinochet es visible la mano judia ${ }^{5 n " . ~ Y ~ a n t e ~ e l ~ p e l i g r o ~ q u e ~ e s t e ~ p l a n ~(q u e ~ n o ~ s o l o ~ e s ~}$ politico sino también mitico y de sangre) significa para Chile, se hace urgente llevar a cabo una colonización del extremo sur por jóvenes nacionalistas chilenos o nórdicos que frenen el avance

Senkman, L. El antisemitismo en la Argentina, Bs. As., Centro Editor de América Latina, 1986, p. 108.

Ibid. p. 110.

4h El Plan Andinia. Estrategia Sionista para apoderarse de la Patagonia Chilena y Argentina, Santiago, 1987, p. 9.

47 [bíd. p. 5 .

4 Ibid., p. 9

49 Ibid.

50 Ibid., p. 10. 
sionista en la zona ${ }^{51}$. Finalmente, hace un llamado a los nacionalistas chilenos y argentinos a trabajar unidos ${ }^{52}$.

Luego, en un apartado de comentarios a los Protocolos incluido en este libro, Serrano afirma que todas las instituciones públicas chilenas están en manos de los judios o de sus agentes, los masones ${ }^{53}$. Critica a las FF. AA. por su perjudicial desconocimiento del "real fin del judaísmo internacional"54, y porque se han dejado infiltrar por el sionismo, a través de Fernando Matthei, que promueve el neoliberalismo o "supercapitalismo" de Milton Friedman y los "Chicago Boys"5s en Chile.

\section{CONTRA LA USURA (1987)}

Este texto es obra del "especialista" en economía de los primeros años del NSDAP, Gottfried Feder, a quien Hitler admirara mientras recorría sus primeros pasos en política, y que predicaba contra el interés y "la usura". Serrano no solo lo editó sino que escribió un breve prólogo, empapado de judeofobia en cuanto "socialismo de los tontos"s6.

El principal argumento que esgrime Serrano en el prólogo es que la usura sería un invento de los judíos para esclavizar a los gentiles, permitiéndoles "vivir sin trabajar": "en el préstamo se desconoció siempre el interés, la usura, la reproducción de la moneda, del metal, de la "cosa", hasta que apareció el parásito, el intermediario e hizo de esa "cosa" un símbolo de sí mismo, otro parásito, otro gusano, bacteria o virus patógeno, canceroso, que se reprodujo enormemente, llegando a ser más importante que el producto y que el hombre productor y trabajador, que el ser humano. El dinero (el "Capital") pasó a ser así el centro único del universo, de la civilización. La "cosa" (la moneda, el dinero) se hizo mercancía principal, destruyendo lo orgánico, la vida. $Y$ el interés con que se la presta, la reproduce ad infinitum, permitiendo a su poseedor, a su amo, vivir sin trabajar, sin producir, a costa del trabajo y de la sangre de la humanidad aria y aun no aria trabajadora, a la que se ha reducido a la esclavitud, a la servidumbre del "interés del capital". Es esta la invención más diabólica que pueda concebirse, llevada a cabo por mentes rabínicas talmudistas, en interpretación fiel a los dictados de su Dios-Drácula, para la aplicación de la explotación y aniquilamiento de los no judios".

Vale mencionar que hacia el final del mismo, Serrano se desliga de cualquier vinculación con la dictadura de Pinochet, acusándolo de imponer un "supercapitalismo" en Chile. Retrata un panorama apocaliptico para Chile, y declara que la única solución sería el nacionalsocialismo y su "modelo" económico: "Yo sostengo e insisto que únicamente el Nacionalsocialismo y su

Ibid., p. 11.

Ibid., p. 11-12.

Ibid, p. 37.

Ibid., p. 40.

Ibíd., p. 55.

Perednik, G. Op. cit, p. 167. 
sus contactos en la escena neonazi mundial, Serrano trae a Chile esta novedad ideológica que tiende a renovar con nuevos bríos viejos motivos antijudios, y la instala como parte de los discursos neonazis contemporáneos.

5. El hilo conductor que guía todo cuanto Miguel Serrano pueda decir respecto de los judíos es el mito conspirativo judio: los judíos del mundo se coluden conscientemente con el objetivo de lograr la conquista y el dominio total sobre los no judíos, y para ello no trepidan en utilizar las más terroríficas armas. Ello salta a la vista especialmente en los textos judeófobos editados y prologados por Serrano, como los Protocolos, El Plan Andinia y El Informe Leuchter.

6. En suma, su relato judeófobo es altamente "quimérico": los discursos judeófobos en general, y el de Serrano en particular, tienden a construir relatos tan abstractos y etéreos (aunque no por ello menos peligrosos en la práctica para sus potenciales víctimas) que terminan por experimentar cierta emancipación de la realidad. Se renuncia a la realidad perceptible con los sentidos a favor de intrincadas construcciones que ubican a la figura de el judio como el promotor y beneficiario de los más indecibles males de la humanidad, como la mano oculta que desde las sombras maneja la Historia para $\mathrm{si}^{62}$. En los textos que hemos revisado los ejemplos sobran:

- El capitalismo y el comunismo son lo mismo. Su oposición es solo aparente. Y ambos pertenecen a manos judías.

- El cristianismo no es distinto del judaísmo, sino que más bien es una creación consciente judía para conquistar a los pueblos no judíos.

- No es lo mismo cristianismo que kristianismo. El primero es "de ellos, los otros"; el segundo, "de nosotros, por ende es el correcto".

- Etc.

"El caso de la judeofobia difiere de la xenofobia. No hay que confrontarse con una interpretación incorrecta, porque no se habla de la realidad cotidiana sino de mitos. Se reivindica el odio a los judíos atribuyéndoles comer a no-judios en el pasado, dominar el mundo en el presente, matar a Dios, inventar el Holocausto, promover las guerras, la esclavitud, el mal. No es fácil contender con argurnentos de esta índole. Éste bien puede considerarse el rasgo esencial de la judeofobia. (...) La judeofobia no guarda relación con el mundo actual, y reposa sobre una ficción alimentada por otras ficciones". En Perednik, G. Op. cit., pp, 31-32. 


\section{CONCLUSIONES: UNA PERSPECTIVA SEMIÓTICA}

Una vez aceptadas estas observaciones, creemos que desde un punto de vista semiótico se pueden plantear las siguientes conclusiones respecto de la judeofobia de Miguel Serrano y su modo de funcionamiento:

1. Serrano, como narrador, es dueño de la designación correcta. En su mundo, compuesto por signos de distinto tipo, el contenido está dado de antemano, y solo basta conocer el orden, el lenguaje (o sea, la correlación entre los elementos de la expresión y los del contenido ${ }^{63}$ ) para acceder a la Verdad. Y él lo conoce. Él sabe qué es qué: sabe que la oposición de comunismo y capitalismo es solo aparente, que la verdad establecida sobre el Holocausto no es tal, sino que él sabe cuál es, etc.

2. Serrano se presume representante de una cultura de signo positivo (conjunto informacional, valórico, etc. desde el cual escribe). Esta cultura correcta, se contrapone a -y en este caso se supone amenazada por- una anticultura, de signo negativo ${ }^{64}$. Esa anticultura es judía, y conspira desde hace milenios para destruir a la cultura, de signo positivo. Y el examen que realiza de la historia chilena reciente se supone que lo confima.

3. Serrano (y también el auditorio al que escribe) tiene cierta "debilidad" por el Libro", por la revelación (en este caso los Protocolos, El Plan Andinia y El Informe Leuchter). Que solo unos pocos (ellos) son capaces de interpretar correctamente.

4. La cultura de signo positivo desde la cual escribe el autor no explicita normas, reglas, valores, conductas, etc. de signo positivo demasiado claras, univocas. Sin embargo, no quedan demasiadas dudas sobre cuáles son las de signo negativo y quién las encarna y promueve entre la humanidad en beneficio propio.

5. Su discurso más que funcionar rígidamente según un corpus de normas relativamente estables, como una gramática, lo hace como un repertorio de empleos ${ }^{66}$, que siempre se puede acomodar con fines antijudios. Así, hasta los rivales ideológicos más enconados (como el capitalismo y el comunismo) pueden ser reducidos a agentes de un mismo amo, judio.

6. La oposición cultural fundamental no será entre principios "ordenado-no ordenado" ( $y$ que por ende deben ser ordenados por nosotros), sino entre el binomio "correctolas Artes y de la Cultura), Madrid, Cátedra, 2000, p. 177. 
incorrecto" (no "no correcto"), incluso "verdadero - falso" 67. Y lo falso, por definición, será patrimonio de lo judio.

7. La anticultura, percibida como cultura de signo negativo, se expande abusivamente. Todas las culturas "incorrectas" (a ojos de Serrano: capitalismo, comunismo, cristianismo, masonería, etc.) se constituyen en un único sistema ("todos son instrumentos judíos").

8. La cultura se recluye sobre sí, prefiere el esoterismo por sobre el proselitismo. La cultura, de signo positivo, no pretenderá jamás expandirse en el campo de la anticultura, incorrecta. Su propagación allí solo seria posible por medio de la victoria de la verdad sobre la mentira ${ }^{68}$, aplastando al universo de signo negativo.

9. Por todo esto, el discurso judeófobo de Miguel Serrano funciona como un sistema cultural orientado predominantemente hacia la expresión ${ }^{69}$.

La judeofobia en las obras de Miguel Serrano que hemos analizado funciona como un programa, que, con cierta flexibilidad, incorpora información a su repertorio y es capaz de adaptar prácticamente cualquier realidad circundante (la obvia rivalidad capitalista-comunista, la distinción entre cristianismo y judaísmo, la abrumadora evidencia sobre el Holocausto, etc.) a su modo de funcionamiento, y expresarlo en sus propios términos, antijudios. La judeofobia de Miguel Serrano, basada en el mito conspirativo judío, sirve para explicarlo todo ${ }^{70}$. La realidad se adapta al lenguaje judeófobo, y luego se interpreta acorde a él.

\section{BIBLIOGRAFÍA}

\section{Fuentes primarias:}

Los Protocolos de los Sabios de Sión y su aplicación en Chile. Santiago, 1981 [2ª ed., León, Wotan, 1988].

67 Ibid, p. 180.

68 lbid., pp. 183-184.

69. Ibid, p. 176.

70) "La teoria de la maquinación es una teoría que vale para todo, pues permite denunciar a unos enemigos invisibles, enmascarados, escondidos, mentirosos, e imputarles acciones inconfesables, con tal de que sean acciones criminales. Se difunde una visión del mundo maniquea, una visión fundada en un principio simplista (y paranoico) para la lectura de todos los acontecimientos, principio que se erige en nueva clase de la historia: la causalidad diabólica del "sionismo internacional" o "mundial" que se manifiesta en todas partes, y que, por consiguiente, todo lo explica". Taguieff, P.-A. La nueva judeofobia, Barcelona, Gedisa, 2003, p. 42. 
El ciclo racial chileno. Santiago, 1985.

La resurrección del héroe. Santiago, 1986.

Nacionalsocialismo, única solución para los pueblos de América del Sur. Santiago, 1986 [2 ed., Santiago, 1997].

Contra la usura. Santiago, 1987.

El Plan Andinia. Estrategia Sionista para apoderarse de la Patagonia Chilena y Argentina. Santiago, 1987.

El Informe Leuchter. Fin de una mentira. Santiago, 1989.

\section{Fuentes secundarias:}

AVNI, H.

Judios en América

Madrid, Mapfre, 1992.

CARO, 1.

Extremismos de derecha y movimientos neonazis

Berlin, Madrid, Santiago. Santiago de Chile, LOM, 2007.

CASALS, $X$.

Ultrapatriotas. Extrema derecha y nacionalismo de la guerra fría a la era de la globalización Barcelona, Crítica, 2003.

COHN, N.

El mito de la conspiración judia mundial: los Protocolos de los Sabios de Sión Madrid, Alianza, 1983.

\section{DEUTSCH, S. M.}

Las derechas. La extrema derecha en la Argentina, el Brasil y Chile. 1890-1939

Bs. As., Universidad Nacional de Quilmes Editorial, 2005.

GOODRICK-Clarke, N.

Hitler's Priestess. Savitri Devi, the Hindu-Aryan Myth and Neonazism

New York, New York University Press, 1998.

LOTMAN, I.; USPENSKI, B.

"Sobre el mecanismo semiótico de la cultura"

En: La Semiósfera, III (Semiótica de las Artes y de la Cultura). Madrid, Cátedra, 2000. 


\section{PEREDNIK, G.}

\section{La judeofobia}

Barcelona, Flor del Viento, 2001.

SAAVEDRA, $M$.

"El neonazismo en Chile"

Artículo inédito.

SCHMIDT, M.

La Alemania neonazi

Barcelona, Anaya \& Mario Muchnik, 1995.

SENKMAN, L.

El antisemitismo en la Argentina

Bs. As., Centro Editor de América Latina, 1986.

TAGUIEFF, P.-A.

La nueva judeofobia

Barcelona, Gedisa, 2003.

The Project for the Study of the Antisemitism

Anti-jewish Propaganda 1991. Tel Aviv University, 1992.

WOJAK, I.

"Chile y la inmigración judeoalemana"

En Milgram, A. (ed.), Entre la aceptación y el odio. América Latina y los refugiados judios del nazismo, Jerusalén, Yad Vashem, 2003. 